\title{
Jurnalisme sebagai Arena Pertarungan Kepentingan: Telaah Teori Kebudayaan
}

\author{
Amirudin \\ Program Studi Antropologi, Fakultas Ilmu Budaya, Universitas Diponegoro Semarang \\ Email: amdjtg@yahoo.com
}

\begin{abstract}
This paper is a theoretical study of the use of cultural theory which played to explain journalism activities that just not an activity to provide accurate information in the public space. In an industrial context, in fact journalism activities has face any complex situation. Now, the activities is no longer exclusively owned by journalists, but journalism is a kind of football arena that have some interest in it. To present news, journalists must be able to absorb various interest from various trajectories. There is a game metaphor that journalists must follow, and how journalist do "practice" the game in the field of contestation, which will be explored using Bourdieu's cultural theory. Through this article, it can contribute to how anthropology plays a role in developing media studies, and vice versa, it can be a trigger for how anthropologists should begin to enter cultural studies which are not just exotic and simple social units; but also entered the study arena into more complex social units, for example in media organizations
\end{abstract}

Keywords: journalism, conflict, interest, practice the game, cultural theory

\section{Intisari}

Artikel ini merupakaan hasil telaah teoritis terhadap penggunaan teori kebudayaan yang dimainkan untuk menjelaskan aktivitas jurnalistik yang bukan hanya merupakan kegiatan untuk memberikan informasi yang akurat di ruang publik saja. Dalam konteks industrial, kegiatan jurnalistik pada kenyataannya juga menghadapi situasi yang lebih rumit. Kegiatan jurnalistik bukan lagi dimiliki secara eksklusif oleh wartawan, tetapi ia adalah semacam arena sepakbola yang memiliki banyak kepentingan yang masuk ke dalamnya. Untuk menyajikan berita, wartawan harus mampu menyerap berbagai kepentingan dari beragam lintasan. Ada semacam metafora permainan yang harus diikuti jurnalis, dan bagaimana jurnalis melakukan "practice" dalam arena kontestasi itu yang akan dibahas dengan menggunakan teori budaya Bourdieu. Melalui artikel ini, penulis berharap dapat memberi kontribusi pada bagaimana antropologi memainkan peran dalam mengembangkan kajian media, dan sebaliknya, paper ini bisa menjadi pemicu bagaimana antropolog harus mulai memasuki kajian budaya yang bukan saja pada unit-unit satuan sosial yang eksotis dan sederhana; tetapi juga memasuki arena studi yang lebih kompleks, dalam hal ini adalah di organisasi media.

Keywords: Jurnalistik, Konflik, kepentingan, praktik permainan, teori kebudayaan 


\section{Pendahuluan}

Jurnalisme merupakan kegiatan menulis berita yang dimulai dari menghimpun fakta dengan investigasi dan wawancara, merekam fakta lalu menuliskannya menjadi informasi dalam bentuk teks berita. Jurnalisme sama dengan kegiatan fiksasi realitas sosial di dunia luar oleh wartawan menjadi teks berita yang mengandung informasi untuk disampaikan kepada khalayak (Hartley, 1992: 25).

Epistemologi jurnalisme diselenggarakan dalam kerangka memenuhi berbagai kebutuhan manusia. Bagi wartawan, Jurnalisme ditujukan untuk melengkapi kebutuhan primer dalam kerangka mendapatkan nafkah; kebutuhan sekunder untuk memperoleh "prestise"; dan kebutuhan integratif untuk mengintegrasikan berbagai pengetahuan serta nilai-nilai yang dimiliki di samping sebagai sarana mengakses ke dalam hubunganhubungan sosial berharga dengan tokoh-tokoh tertentu (Henshall and Ingram, 2000:21).

Bagi pembaca sebagai warga dari suatu negara, jurnalisme dibutuhkan dalam kerangka memenuhi hak untuk tahu dan hak membentuk dan mengungkapkan pikiran dan pendapatnya secara bebas. Jurnalisme dibutuhkan sebagai sarana mengakses informasi bebas sebagai dasar membentuk keputusan-keputusan berharga untuk berpendapat dan bertindak bagi warga negara (Siregar, 2000: 135).

Bagi pemilik perusahaan pers, karena Jurnalisme adalah kegiatan yang menjadi komoditi utama dalam konteks dunia pers saat ini, yakni konteks bersifat industrial bertolak dari faktor-faktor bersifat ekonomi di antaranya peranan modal dan persaingan merebut pasar, maka jurnalisme diadakan dalam kerangka mendapatkan keuntungan ekonomi (return of investment). Pemilik modal tidak berkeinginan "gulung tikar" dari seluruh modal yang telah ditanam untuk membangun bisnis pers (Yasraf Amir Piliang, 2000: 62).

Dari sudut pandang itu, jurnalisme merupakan bagian dari kegiatan manusia yang tak terpisahkan dari penjuangan membentuk, menanam dan memperjuangkan kekuasaan. Kekuasaan dalam pengertian yang bukan subyektif artinya tidak sekedar menyangkut kemampuan dasar manusia untuk memaksakan kehendak terhadap yang lain, tetapi dalam konteks struktural dan simbolis, yakni yang mengandung arti memaksa dan mengatur hubungan subyek obyek dan prosesproses fisik maupun teknis dan suatu kegiatan. Dengan kata lain, kekuasaan yang mengambil bentuk menjadi pengetahuan berwujud pernyataanpernyataan logis (discourse) yang secara perlahan memaksa orang untuk patuh. 
Para pelaku yang menjalankan dan berada di sekitar wilayah jurnalisme menempati struktur kekuasaan yang adalah dominasi. Konsep kekuasaan dalam pengertian itu tidak melihat fenomena dominasi dalam konteks yang homogen, maksudnya tidak terbatas pada dominasi individu yang satu terhadap yang lain, kelompok yang satu terhadap yang lain, atau kelas sosial yang satu terhadap yang lain; tetapi dominasi dalam kaitan langsung dengan bidang penerapan tertentu di mana terdapat akibat-akibat riil dari kekuasaan. Kekuasaan memasuki semua lini kegiatan manusia termasuk kegiatan jurnalisme dan mengatur perilaku wartawan yang menempati tubuh sosial perusahaan pers.

Dalam sirkulasi kekuasaan, wartawan bisa mendapatkan kesenangan tetapi sebaliknya penderitaan. Memperoleh kesenangan karena ia mendapatkan penghargaan material dan non material, sebaliknya penderitaan karena ia mengalami kerugian. Habitat kekuasaan dengan demikian menjadi tak terbatas, artinya, kekuasaan pada kenyataannya merasuk ke mana-mana, ada di mana-mana membentuk jaringan subtil dari wacana, pengetahuan dan kenikmatan. Foucault (1972: 78) mempertegas dua hal; pertama, dalam wacana, antara kekuasaan dan pengetahuan sangat terkait karena bahasa menjadi alat untuk mengartikulasikan kekuasaan pada saat kekuasaan harus mengambil bentuk pengetahuan. Kekuasaan pengetahuan terkosentrasi dalam kebenaran pernyataan-pernyataan logis.

Dalam dunia jurnalisme, pernyataan-pernyataan itu bisa keluar dari sumber berita, siapapun mereka-pejabat, politisi, tokoh masyarakat, tokoh agama dan akademisi-atau bahkan pengelola koran seperti pemimpin umum, pemimpin perusahaan, pemimpin redaksi, dan para redaktur. Mereka berusaha mengontrol dan mengatur wacananya padahal strategi kekuasaan melekat pada kehendak yang merangsang orang untuk mengetahui. Orang cenderung ingin tahu, termasuk wartawan, maka semua wartawan cenderung menjadi subyek potensial bagi perputaran kekuasaan.

Kedua, kekuasaan bekerja dalam suatu jaringan. Dalam jaringan itu, seseorang selalu dalam posisi menjalankan kekuasaan atau menderita kekuasaan. Kekuasaan tidak bisa dimiliki, tetapi bersirkulasi. Orang biasanya berada dalam sirkulasi kekuasaan dan sering mengikuti arusnya untuk bisa bertahan. Maka, bukan seseorang yang memberi bentuk kepada kekuasaan, tetapi pertama-tama kekuasaan yang membentuk dan menghasilkan perilaku seseorang.

Dalam dunia pers, cara kerja kekuasaan pertama-tama menunjuk pada prosedur. Analisa itu memungkinkan untuk mengetahui mengapa prosedur disipliner harus 
diberlakukan. Kekuasaan disipliner ingin membuat keseluruhan wartawan patuh. Hal itu mengandaikan teknologi politik dalam dunia jurnalisme, yaitu keseluruhan cara kerja yang dapat mengatur mereka di bawah kekuasaan. Foucault (1972) menggunakan istilah mekanisme panoptik sebagai alat analisa teknologi politik.

Prinsip panoptik adalah pengawasan yang dilakukan secara tidak teratur, tetapi efeknya dalam kesadaran perasaan terus menerus diawasi. Meski pengawasan dilakukan secara tidak kontinyu efeknya berlangsung secara permanen. Maka kekuasaan yang paling sempurna, aktualitas pelaksanaannya makin tidak diperlukan, tetapi efeknya sungguh sangat dirasakan.

Tujuan panoptisme adalah memperoleh kepatuhan dengan meminimalisir tindakan yang sulit diperhitungkan. Di dunia pers, bentuk mekanisme panoptisme bisa dilihat dan kode etik jurnalistik yang disusun Dewan Pers dan teknik jurnalistik yang disepakati dan dikembangkan di setiap koran. Dalam bentuk lain banyak ditemui dalam bentuk mediawatch, dewan pembaca, dan lain-lain. Kesemua itu merupakan contoh bentuk pendisiplinan paling nyata yang dilakukan kepada wartawan untuk patuh.

Kekuasaan pada kenyataannya merasuk ke mana-mana, ada di mana-mana membentuk jaringan subtil dan wacana termasuk dalam Jurnalisme hingga potensial melahirkan konflik. Dalam kaitan dengan penelitian ini, secara hipotetis dapat dikatakan bahwa konflik jurnalisme sesungguhnya muncul ketika setiap pelaku jurnalisme yakni sumber berita, wartawan, redaktur, pemimpin redaksi dan pemilik modal mengalami benturan kekuasaan.

Berdasarkan hal itu, maka bagaimana kekuasaan mengambil bentuk menjadi wacana yang memiliki kaitan dengan kemunculan konflik dalam proses Jurnalisme itu yang menjadi fokus dari telaah teortik kebudaan di artikel ini. Hasil dari telaah teortik diharapkan dapat menambah pengetahuan mengenai dinamika sosial budaya yang berlangsung dalam tubuh perusahaan pers ketika memproduksi berita. Di samping itu juga dapat membantu pengelola media dalam merumuskan model-model penyelesaian konflik di perusahaan pers. Manfaat lain diharapkan dapat melengkapi studi media yang selama mi jarang dilakukan dengan pendekatan sosial budaya.

\section{Jurnalisme sebagai Praktik: Telaah Teori Kebudayaan Bourdieu}


Paper ini dikemas dengan menggunakan pendekatan kebudayaan Bourdieu, sebuah pendekatan yang tergolong post-modernisme yang rnulai diterima menjadi konstruksi teoritis dalam penelitian sosial humaniora di pertengahan 1980-an (Alam, 1998:1-11). Inti dari teori kebudayaan Bourdieu terletak pada konsep practice (praktik) yang pengertiannya tidak bisa disamakan dengan konsep tindakan dalam sosiologi Weber yang kemudian diwariskan pula ke dalam pendekatan interpretatif Geertz. Berbeda dengan konsep tindakan dalam tradisi Weberian yang cenderung dilihatnya sebagai pencerminan ide-ide yang terkandung dalam kebudayaan si pelaku, sedang konsep praktik menekankan pada hubungan timbal balik antara si pelaku dan apa yang oleh Bourdieu disebut struktur obyektif yang mencakup pula kebudayaan sebagai sistem konsepsi yang diwariskan secara turuntemurun (Bourdieu, 1977: 83).

Bourdieu menggambarkan hubungan timbal balik di antara keduanya seperti berikut. Pertama, struktur obyektif diproduksi secara terus-menerus dalam praktik para pelakunya yang berbeda dalam kondisi historis tertentu. Kedua, dalam proses tersebut para pelaku mengartikulasikan dan mengaprosiasi simbol-simbol budaya yang terdapat dalam struktur obyektif sebagai tindakan strategis dalam konteks sosial tertentu. Ketiga, proses timbal balik yang terjadi secara terus-menerus antara praktik dan struktur obyektif itu dapat menghasilkan baik perubahan maupun kontinyuitas.

Pemunculan konsep praktik dalam teori kebudayaan Bourdieu sesungguhnya tidaklah lahir dalam situasi vakum, tetapi tumbuh dalam situasi perdebatan keras antara dua aliran besar dalam ilmu sosial yakni idealisme versus empirisme, atau subjetivisme versus objektivisme. Tindakan Bourdieu untuk mengatasi celah yang terbentang di antara dua paham pemikiran yang saling bertentangan itu adalah dengan membuat sebuah jembatan melalui konsep yang disebutnya habitus. Secara literal, konsep ini berasal dari bahasa latin yang mengacu pada pengertian "yang dilakukan karena kebiasaan atau kondisi yang khas khususnya dan tubuh si pelaku" (Bourdieu dalam Jenkins, 1992:74).

Bourdieu (1977:72) mendefinisikan habitus sebagai ..., "system of durable, transportable disposition, structured structures predisposed to function as structuring structure, that is as principles of the generation and structuring praktikand representation which can objectively 'regulated' and 'regular' without in any way being the product of obedience to rules,..." 
Pengertian habitus dalam bahasa yang sederhana bisa digambarkan sebagai kebudayaan yang diturunkan dan generasi ke generasi, dari jaman ke jaman, dari kelompok kelas ke kelompok kelas yang diintemalisasikan oleh individu dalam wujud disposisidisposisi yang ekaligus menjadi acuan dalam tindakan-tindakannya.

Pemunculan konsep habitus adalah untuk menegaskan bahwa individu yang subjektif ternyata juga sosial dan kolektif. Habitus dengan demikian merupakan sosialiasi subjektivitas. Maka unsur terpenting yang tidak bisa diabaikan dalam teori kebudayaan Bourdieu adalah menempatkan hubungan antara tubuh si pelaku dan habitus, bagaimana disposisi-disposisi itu ditampilkan oleh si pelaku. Bourdieu (Jenskin, 1992:74) menunjukkan bahwa tampilan wujud dan disposisi itu berada dalam tiga hal. Pertama, habitus hanya hidup karena ia berada dalam kepala manusia-kepala bagaimanapun merupakan bagian dari tubuh manusia. Kedua, habitus ada karena praktik yang dilakukan oleh pelaku-pelaku (aktor) dan interaksi di antara mereka secara terus-menerus dalam lingkungan sosialnya. Yang terakhir termasuk juga praktek-praktek sistem klasifikasi (laki/perempuan, atas/bawah, kaya/miskin, jujur/tidak jujur, dll) yang menyebabkan terbentuknya pola-pola habitus ada dalam setiap diri pelaku.

Habitus unsurnya berasal dari kebiasaan-kebiasaan yang sudah tidak terpikirkan dan bukannya secara sadar mempelajari aturan-aturan atau prinsip-prinsipnya. Secara sosial, unsur dan perbuatan diciptakan menjadi semacam bahan-bahan kebiasaan sehari-hari, tanpa acuan eksplisit pada sistem pengetahuan tanpa si pelaku mengetahui apa yang sesungguhnya sedang dikerjakan.

Habitus dengan demikian merupakan perantara (mediasi) antara prinsip-prinsip struktural dan kebudayaan dan prinsip struktural yang dimiliki oleh praktik si pelaku serta ia sendiri adalah struktur dari wujud struktur dan prinsip-prinsip lainnya. Dalam kaitannya dengan hal itu, maka habitus bisa dipahami dalam tiga bentuk. Pertama, collective habitus yakni penyatuan simbol-simbol dan konsepsi-konsepsi yang terkandung dalam kebudayaan; kedua dispositional habitus yakni internalisasi simbol-simbol dan konsepsi-konsepsi yang terkandung dalam kebudayaan, dan yang terakhir manfest habitus yaitu praktik dan corak mode yang khas (R. Nash, 1990:434).

Titik tekan habitus adalah bahwa habitus merupakan satu konstruksi mediasi, bukannya yang metentukan praktik. Praktik adalah hasil pertemuan antar habitus lengkap 
dengan disposisi-disposisinya di satu sisi, dan konsteks sosial tertentu di mana si pelaku melaksanakan tindakan-tindakannya, di lain sisi.

Bagi Bourdieu (Jenkins, 1992:69-71) praktik bisa dipilah berdasar tiga ciri pembeda. Pertama, praktik selalu berada dalam ruang dan waktu. Konsep waktu sebagaimana diketahui juga merupakan hasil konstruksi secara sosial yang berbeda dengan konsep siklus alam - pagi, siang, sore, atau umur dan semacamnya. Secara intrinsik, praktik didefinisikan oleh waktu, artinya sebagai gejala sosial yang teramati, praktik tidak bisa dipahami di luar kerangka ruang dan waktu. Kedua, praktik diorganisasikan dengan sepenuhnya sadar, dalam arti tidak ada yang tidak disengaja atau hanya kebetulan. Praktik memberikan feel for the game berupa perasaan mengenai apa yang cocok dan yang tidak cocok dalam satu keadaan. Sebuah kebutuhan untuk menyatu dengan dunianya. Banyak orang menyatakan diri sendiri dan dunia sosial sebagai sesuatu yang terjadi begitu saja. Ia tidak memikirkannya karena memang tidak memiliki dan dimilikinya. Bourdieu menyebutnya sebagai doxa.

Bourdieu (Jenkins, 1992:70) mengungkapkan doxa sebagai “..., the coincidence of the objective structures and the internalized structure which provides the illusion of immediate understanding, characteristic of practical experience of the familiar universe and which at the same time excludes from the experience any inquiry as to its own condition ofpossibility,..."

Field juga merupakan sistem kekuatan yang hadir di antara berbagai posisi tersebut, ia terstrukturkan secara internal dalam istilah hubungan kekuasaan. Posisi itu menggambarkan hubungan dominasi sub-ordinasi atau hubungan setara berdasarkan keunggulan masing-masing kekuatan yang dimiliki oleh modal yang dipertaruhkan dalam arena sosial.

Jenkins (1992:86) menyebutkan bahwa penggunaan konsep field memerlukan tiga cara. Pertama, ia ditaruh dalam arena sosial kekuasaan untuk mengenali kekuasaan yang dianggap dominan atau yang paling unggul dalam masyarakat, dan mengenali sumber dan hubungan kekuasaan yang hirarkhis yang menjadi kerangka bagi arena sosial lainnya. Kedua, mengkonstruksikan peta dari masing-masing posisi yang menyusun arena sosial dan hubungan di antara mereka yang terlibat persaingan di dalamnya. Ketiga, habitus dari masing-masing pelaku dalam field dianalisis sejalan dengan strategi-strategi yang merupakan produk dan interaksi antar habitus dan batasan-batasan serta kesempatan yang ditentukan oleh kerangka arena sosialnya. 


\section{Jurnalisme sebagai Medan Konflik}

Dalam kajian kebudayaan organisasi, definisi mengenai konflik banyak ditemukan dalam berbagai literatur. Dessler (1992:414) umpamanya mendefinisikan konflik sebagai perilaku manusia yang melawan pihak lain yang memaksakan kehendaknya dalam suatu organisasi. Prosesnya dimulai sejak ia merasakan adanya bentuk-bentuk perlawanan dan pihak lain ketika berusaha mencapai tujuan dan kepentingan. Dalam hal itu, yang namanya konflik selalu bermula dan tindakan dan pihak lain yang dirasakan sebagai bersebarangan dengan kepentingan-kepentingannya.

Definisi lain dikemukakan Robbins (1990:451) yang mengatakan konflik sebagai tindakan yang sengaja dibuat dalam bentuk tersembunyi maupun terbuka. Lengkapnya, konflik merupakan suatu proses di mana seseorang melakukan usaha yang sengaja dibuat untuk mematahkan usaha-usaha orang lain dengan berbagai cara sehingga mengakibatkan frustasi di pihak lain ketika berusaha mencapai tujuan dan meneruskan kepentingankepentingannya.

Ada tiga kriteria yang dapat menjadi tolak ukur untuk mengetahui konflik menurut kedua ahli itu, pertama, jika ada pihak-pihak yang merasakan adanya konflik. Ada di antara anggota organisasi yang merasakan dirinya terancam karena tindakan pihak-pihak lain yang menggangu pencapaian tujuan dan kepentingan-kepentingannya. Kedua, adanya maksud yang sengaja dipaksakan untuk menghalang-halangi tujuan dan kepentingan pihak lain. Ketiga, jika ada tindakan terbuka dari pihak-pihak yang menghalang-halangi tujuan dan kepentingan maupun tindakan terbuka dan pihak yang dihalang-halangi. Tindakan terbuka dalam pengertian ekstrim, menurut kedua ahli itu, bisa tanda-tanda pertikaian maupun pertarungan terbuka.

Berbeda dengan pendekatan interaksionis, pendekatan ini menganggap, konflik merupakan sesuatu yang dibutuhkan organisasi. Organisasi yang tidak memiliki konflik sama saja organisasi itu statis, apatis, dan tidak responsif terhadap kebutuhan melakukan perubahan. Bagi pendekatan ini, konflik sesungguhnya fungsional karena ia dapat memprakarsai lahirnya kreativitas dan inovasi dalam mencapai tujuan-tujuan organisasi.

Pendekatan interaksionis menganggap perubahan adalah esensial dan perubahan itu muncul jika ada stimulus yang fungsional. Stimulus itu adalah konflik yang bekerja secara intensif berdaptasi merangsang lahirnya kebutuhan untuk berubah yang akhirnya bermuara 
pada survive-nya organisasi. Menurut Robbins (1974: 23), dalam kerangka menuju perubahan syaratnya satu, harus ada rasa ketidakpuasan terhadap status-quo. Dengan kata lain, organisasi yang mempertahankan status-quo, artinya tidak ada konflik, berarti tidak memiliki kekuatan internal untuk melakukan perubahan.

Namun demikian, pendekatan interaksionis tidak sepenuhnya menganggap, semua konflik adalah fungsional. Di tingkat tertentu ada konflik yang mampu menimbulkan dampak buruk terhadap keefektifan organisasi. Dalam hal itu, sebagaimana pendekatan tradisional, manajemen dituntut mampu mengelola konflik seefektif mungkin. Pendekatan interaksionis secara tidak langsung menempatkan peran begitu besar kepada Chief Executive Officer (CEO) dalam mengelola konflik dibandingkan pendekatan tradisional. Pekerjaan CEO adalah menciptakan suatu lingkungan di mana konflik harus sehat dan tidak membiarkan konflik tumbuh menjadi ekstrim.

Dalam pendekatan interaksionis, tingkat konflik tidak dibenarkan menjadi terlalu rendah atau sebaliknya terlalu tinggi. Di tingkat yang terlalu rendah, konflik dapat melahirkan sikap apatis, stagnasi, dan anti perubahan dari para anggota. Oleh karenanya harus diupayakan lahirnya konflik guna mendapatkan keuntungan dan sifat fungsional konflik. Sifat fungsional itu antara lain, konflik bisa merangsang gairah, sikap kritis dan inovatif dari para anggota organisasi. Sebaliknya, di tingkat yang terlalu tinggi, konflik yang kemungkinan bisa mendatangkan kekacauan, kesemrawutan, dan sikap tidak kooperatif, menuntut CEO mampu mengelola konflik ke tingkat yang optimal sehingga kembali fungsional. Kedua pendekatan itu dalam tesis ini akan dipakai untuk melihat kecenderungan respon para pelaku jurnalisme kepada konflik, apakah cenderung tradisionalis atau sebaliknya interaksionis.

Banyak faktor bisa melahirkan konflik. Robbins (1990: 457) menyebut di antaranya faktor psikologis yang menyangkut karakter pesonal perseorangan. Banyak orang kenyataannya memiliki kesulitan untuk bekerjasama dengan yang lain sementara kesulitan itu sesungguhnya tidak ada kaitannya dengan kemampuan kerja dan orang tersebut. Di samping itu faktor struktural. Dalam kaitannya dengan hal ini, tesis ini berusaha memfokuskan kajiannya pada sumber-sumber struktural yang mempengaruhi lahirnya konflik sebagaimana diungkap Bourdieu (1985).

Menurut Bourdieu (1985:56), dalam dunia jurnalisme, konflik muncul sebagai konsekuensi dan anggapan mengenai organsisasi yang bukan saja sebagai ruang sosial 
berdimensi satu (unidemensional), yakni ruang sosial yang terbangun oleh kelas-kelas sosial serta selalu berada dalam relasi kelas melalui beroperasinya dimensi ekonomi. Lihat teori Marxis dan Neo Marxis yang banyak melihat organisasi sebagai fenomena unidimensional, walaupun sebenarnya keduanya berbeda dalam hal analisis kelas dan hubungan sosial antar kelas.

Dalam buku Distinction (1985:67), Bourdieu memperkenalkan pemisahan mendasar antara apa yang disebut modal ekonomi (economic capital), dan modal kebudayaan (culture capital) yang merupakan dimensi tak terpisahkan dari paham ekonomisme dan kulturalisme untuk menganalisis proses kemunculan konflik dalam dunia jurnalisme. Menurut Bourdieu (1985), wilayah kebudayaan termasuk Jurnalisme tidak harus dinilai sebagai efek samping dari beroperasinya modal ekonomi, melainkan ia adalah sebuah wilayah otonom yang memiliki bentuk kekuasaan, sistem pengetahuan, dan pasar simboliknya sendiri. Singkatnya perusahaan pers sebagai sebuah ruang sosial ternyata merupakan ruang sosial dalam dua dimensi (dual-dimensional), yakni ruang sosial bentukan modal ekonomi dan modal kebudayaan yang masing-masing dihuni oleh para pendukungnya masing-masing.

Struktur ruang sosial perusahaan pers dengan demikian terbentuk sebagai hasil beroperasinya modal ekonomi dan modal kebudayaan, serta juga merupakan akibat dari struktur kapital yang tertanam yang menentukan munculnya fraksi dominan ekonomi dan fraksi dominan kebudayaan dalam kelas sosial yang paling berpengaruh. Sementara di lain sisi, kelas popular tidak bisa menampilkan dinamikanya atau bahkan justru bersifat homogen. Hal itu merupakan konsekuensi dan munculnya dua dimensi ruang sosial, yakni ruang sosial yang dibentuk melalui modal ekonomi dan modal kebudayaan yang mengarah pada penggunaan kebudayaan tinggi sebagai acuan yang seolah-olah legal untuk menilai mana hasil kerja jurnalisme yang baik dan mana yang buruk dan kelas popular.

Kelas dominan dibandingkan dengan kelas popular, di mana dalam hubungan antar kelas, segala tingkah laku mereka, biasanya didasarkan atas kategori yang terdefinisikan oleh apa yang dimiliki kelas dominan saja. Akibatnya posisi kelas popular serta kondisi obyektif (cara berpikir dan perilaku) mereka dalam ruang sosialnya semuanya didefinisikan oleh apa yang dimiliki kelas dominan dan apa yang tidak dimiliki kelas popular. Demikian pula terhadap habitus yang dimiliki kelas popular, didefinisikan secara negatif dan apa yang tidak mereka miliki oleh kelas dominan, bahkan selera (taste) dalam menulis berita pun diperlakukan sebagai negasi dan selera kelas dominan yang dinamis sehingga kebudayaan 
kelas popular beresiko muncul sebagai kebudayaan monoton yang statis. Kebudayaan yang merupakan bias representasi atau cermin dari kebudayaan kelas dominan.

Sekalipun sebenarnya, kelas popular secara empirik memiliki potensi serta kemungkinan untuk menjadi tempat munculnya dua fraksi kelas sosial popular, yakni fiaksi dominan ekonomi dan fraksi dominan kebudayaan. Potensi tersebut hanya mungkin dapat dicapai jika wacana khusus mengenai modal ekonomi yang berpengaruh itu digantikan sebagai wacana yang lebih umum sifatnya berupa penggabungan antara modal ekonomi dan modal kebudayaan secara makro sebagai orientasi investasi yang membentuk fungsi superiotasnya sendiri-sendiri di ruang sosialnya sendiri.

Dalam pandangan Bourdieu, ketika investasi kebudayaan adalah utama, maka modal dan nilai adalah kekuasaan penentu yang menentukan manakah suatu berita itu dikatakan bernilai atau tidak bernilai. Hal itu dapat dicontohkan dalam kegiatan jurnalisme dari para jurnalis yang berada di kelas popular. Ekspresi berita dan kelas popular tidak mungkin dapat bernilai karena tidak dapat ditransformasikan menguntungkan secara ekonomi atau tidak komersial dalam perspektif pemilik modal. Padahal belum tentu berita buatan mereka lebih buruk dalam pengertian tidak diminati pembaca.

Sebaliknya, pemilik modal adalah pemegang kekuasaan ekonomi yang otonom yang menentukan mana berita yang bernilai dan yang tidak. Mereka dapat menentukan mana berita yang dianggap syah untuk dimuat dan mana yang tidak. Masalahnya hanya terletak pada kriteria mana yang memungkinkan pembedaan yang sah dan mana yang tidak sah dan bentuk ekspresi lain mengingat berita memiliki otonomi sendiri. Tidak ada konsensus bersama mengenai baik buruknya berita, masing-masing kelas memiliki persepsinya sendiri-sendiri. Namun patut dicatat bahwa jika pemisahan itu telah dilakukan sejak awal, pemisahan itu membawa konsekuensi memiliki kekuasaan otoriter yang menepertajam semangat perbedaan.

Produksi berita inferior (low taste news) yang dianggap tidak bernilai berita karena tak miliki nilai jual yang menyangga modal. Namun itu bukanlah menjadi petanda bahwa berita mereka tidak memiliki nilai bagi kelas popular, khususnya untuk fraksi dominan kebudayaan. Sesungguhnya kebudayaan itu memiliki kekuatan untuk menyerap dan menerima tanpa kesulitan melakukan bentuk pengucilan bahkan kekerasan simbolik (symbolic violence) yakni pada saat mekanisme pengucilan secara tidak etis dilakukan, misalnya ketika para jurnalis yang berasal dari kelas popular mencoba masuk dalam wilayah 
kelas sosial dominan, tetapi tidak diperbolehkan karena wilayah kelas sosialnya diisolasi. Atau sebaliknya ketika justru segala macam hasil karya Jurnalisme kelas popular itu hanya dikatakan bernilai jika sesuai dengan perspektif kelas dominan saja.

Inilah persoalannya; bagaimana mereka yang coba bertahan berkarya dalam ruang sosialnya sendiri, terpaksa harus bersedia menginternalisasi nilai-nilai dan preferensi kebudayaan yang dianggap syah oleh kelas dominan, termasuk dalam menulis berita. Jika tidak maka ia harus berkonflik dengannya. Berita yang tidak bernilai komersial, yang oleh kelas popular ditolaknya, akan tetapi demi kepentingan pemilik modal, maka mereka tidak mampu menolak bahwa berita yang komersial adalah berita yang bernilai. Ini berarti, sebuah berita hanya dapat bernilai diukur berdasarkan kondisi dan investasi ekonomi kelas popular saja yang memiliki nilai ekonomi secukupnya untuk fraksi dominan ekonomi kelas popular bukan untuk kelas dominan di atasnya.

\section{Simpulan}

Jika kekuatan konflik terlalu besar maka dikatakan bahwa itu merupakan penyelewengan dan fungsi konflik (Dessler, 1992:432). Kekuatan itu jadi memiliki dampak negatif bagi keefektifan organisasi. Oleh karenanya, langkah resolusi harus dilakukan untuk menurunkan konflik sampai pada tingkat yang dapat diterima. Yang disebut di bawah ini merupakan teknik-teknik struktural untuk mengurangi konflik.

Pertama, dengan jalan rekonsiliasi. Dalam langkah ini pihak-pihak yang terlibat dalam konflik secara sadar dan terbuka berupaya untuk berdamai secara suka rela dengan pihakpihak lain yang dianggap lawannya. Di sini yang berlangsung adalah terjadinya interaksi secara jujur untuk saling mengakui dan memaafkan atas segala kesalahan yang mereka jalankan. Komunikasi yang terjadi bersifat jujur tanpa ada upaya untuk melakukan muslihat apapun. Biasanya jalinan komunikasi yang terjadi bersifat interpersonal dan informal, sehingga tidak ada halangan yang dapat menghambat keinginan untuk saling mengakui kesalahan-kesalahan yang telah dilakukan, saling memaafkan dan berdamai ini.

Kedua, dengan jalan menghadirkan mediator. Apabila masing-masing pihak ternyata mengalami kesulitan untuk menjalankan rekonsiliasi, maka yang ditempuh biasanya adalah mencoba mengundang salah seorang atau beberapa pihak yang dapat menjadi penengah (mediator) di antara mereka yang berkonflik. Mediator ini dapat diundang oleh dua kubu yang saling bertentangan atau dapat juga mediator ini hadir karena inisiatifnya sendiri. 
Sehingga dengan kehadiran mediator ini dapat dijadikan sebagai pihak yang menjembatani kekakuan serta keengganan di antara mereka yang berselisih untuk melakukan komunikasi. Hanya saja apapun yang diputuskan oleh pihak mediator tidaklah mempunyai sifat yang mengikat. Keputusan-keputusannya dapat diterima dan dilaksanakan apabila memenuhi kehendak mereka yang bertikai, atau dapat juga ditolak sama sekali karena dianggap tidak memberikan solusi yang terbaik.

Ketiga, dengan menghadirkan pihak ketiga sebagai wasit (referee). Pola ini lazim disebut sebagai resolusi konflik dengan jalan arbitrase. Ini berarti bahwa kesemua pihak yang bertikai merasakan tidak puas dan tidak mampu dengan resolusi-resolusi konflik yang telah ditempuh sebelumnya, baik dengan cara rekonsiliasi maupun mediasi. Mereka yang bertikai merasakan bahwa pemecahan yang terbaik adalah dengan jalur legal-formal yang dapat digunakan sebagai acuan yang tegas serta mengikat. Di sini, resolusi konflik dijalankan melalui mekanisme layaknya dalam sebuah proses pengadilan di mana secara sengaja dihadirkan seorang hakim yang harus memutuskan perkara secara adil dan sebaikbaiknya, sehingga dapat diterima oleh semua pihak. Keputusan apapun yang dijalankan melalui proses harus diterima oleh mereka yang bertikai, karena bersifat mengikat.

\section{Daftar Pustaka}

Alam, Bachtiar. 1998. 'Globalisasi dan Perubahan Budaya: Perspektif Teori Kebudayaan'.Antropologi Indonesia 21 (54): 1-11.

Asad, Talal. 1993. Anthropological Conceptions of Religion: Reflections of Geertz. dalam Bahtiar Alam Globalisasi \& Perubahan Budaya: Perspektif Teori Kebudayaan. Jurnal Antropologi No.54 hal. 1

Bourdieu, Pierre. 1970. Reproduction. London: Routledge.

Bourdieu, Pierre. 1977. Outline of a Theory of Practice. Diterjemahkan R. Nice. Cambrice: Cambridge University Press.

Bourdieu, Pierre. 1985. Distinction. A Social Critique of Judgement of Taste. London: Routledge \& Kegan Paul.

Bourdieu, Pierre. 1992. Language \& Symbolic Power. Cambridge: Polity Press.

Bourdieu, P. and Loic J.D. Wacquant. 1992. An Invitation to Reflexive Sociology. Chicago: University of Chicago Press.

Budary, M. Said Budairy. 2001. “Wartawan Amplop”. dalam Pantau Tahun III Nomor 015Juli 2001, hal. 6263.

Calhoun, Craig (ed.). 1993. Bourdieu: Critical Perspectives. Cambridge: Polity Press.

Chesney, Robert Mc. 1997. Corporate Media \& the Threat to Democracy. New York: Seven Stories Press.

Dessler, Garry. 1992. Organization Theory: Integrating Structure and Behavior. 2"' 3ed. New York: Prentice Hall. 
Foucault, Micahel. 1972. Power/Knowledge. New York: Pantheon.

Geertz, Clifford. 1971. The Interpretaion of Culture. London: Routledge.

Giddens, Anthony. 1984. The Constitution of Society: Outline of the Theory of Structuration. Berkeley: University of California Press.

Golding, Peter and Graham Murdock. 1997. The Political Economy of the Media. Vol. 1. Chentelham: Edward Edgar Publishing Limited.

Hartley, John. 1992. Understanding News. Routledge. London.

Hatch, Mary Jo. 1997. Organization Theory: Modern, Symbolic, and Potsmodern Perspectives. New York: Oxford University Press.

Henshall, Peter and Ingram, David. 2000. Menjadi Jurnalis. Jakarta: Institut Studi Arus Informasi.

Hofstede, Geert. 1991. Culture and Organizations: Software of the Mind. Toronto: McGraw- Hill Book Company.

Jatman, Darmanto. 1999. Rekonsialisasi Konflik Domestik, Tinjauan Psikologi Kebudayaan. Naskah Pidato Dies Natalis Undip Ke-42 16 Oktober 1999 di Auditorium Undip.

Jenskin, Richard. 1992. Key Sociologiest Pierre Bourdieu. London: Routledge.

Krisnawan, Yohanes. 1997. Pers Memihak Golkar? Suara Merdeka dalam Pemilu 1992. Jakarta: ISAI.

Nash, Roy. 1990. 'Bourdieu on Education and Social and Cultural Reproduction'. British Journal of Sociology of Education, vol 11, Non 4, 1990, P. 431-447.

Piliang, Yasrah, Amir. 2000. 'Hegemoni, Kekerasan Simbolik dan Media: Sebuah Analisis tentang Ideologi Media'. Kupas Jurnal Mediawatch. (5): 62

Pontoh, Coen Husain. 2001. 'Konflik Tak Kunjung Padam'. Jurnal Pantau. (016): 44-61.

Robbins, Stephen P. 1990. Organization Theory: Structure, Design, and Aplications. N.J. Englewood Cliffs.

Siregar, Ashadi. 2000. 'Jurnalisme damai, Resolusi Konflik Sosial'. Sendi Jurnal Mediawatch \& Civic Education. (4-5): 135

Stevenson, Nick. 1995. Understanding Media Culture: Social Theory and Moss Cornunication. New Delhi: sage Publications. 